Ritrýnd grein birt 31. desember 2020

\title{
Milliliður, stuðningsaðili eða hlutlaus fylgdarmaður: Hlutverk aðstoðarfólks í námi fólks með proskahömlun sem parf mikinn stuðning
}

\author{
Helle Kristensen og Kristín Björnsdóttir \\ Abstract \\ Um höfunda \\ About the authors \\ Heimildir
}

Fólk með proskahömlun sem parf mikinn stuðning hefur haft takmarkaðan aðgang að námi og litla möguleika til að nýta sér nám í daglegu lífi. Gera má ráð fyrir að peim fjölgi sem geta nýtt sér aðstoðarfólk úr búsetupjónustunni í námi. Pví er pörf á að skilgreina hlutverk aðstoðarfólks betur í námi fatlaðs fólks. Tilgangur greinarinnar er að lýsa rannsókn sem hafði pað að markmiði að fá innsýn í hvernig aðstoðarfólk sér fyrir sér hlutverk sitt.. Pátttakendur í rannsókninni voru sex aðstoðarmenn sem höfðu reynslu af að fylgja fólki á námskeið hjá Fjölmennt, símenntunar- og pekkingarmiðstöð. Fólkið sem naut aðstoðar peirra tjáði sig með óhefðbundnum tjáskiptaaðferðum og purfti mikinn stuðning í daglegu lífi. Um er að ræða eigindlega rannsókn sem fram fór á tímabilinu mars 2018 til janúar 2019. Í niðurstöðunum kom fram hvernig viðmælendur mótuðu hlutverk sitt og greind voru prjú ólík hlutverk aðstoðarfólks sem í rannsókninni nefnast milliliðurinn, stuðningsaðilinn og hinn hlutlausi fylgdarmaður. Pættir sem höfðu áhrif á hvernig hlutverkið mótaðist voru meðal annars sýn aðstoðarfólksins á hlutverk kennarans sem og viðhorf aðstoðarfólks til starfsins og til náms peirra sem pað aðstoðaði. Einnig virtist skipulag pjónustunnar og skortur á sameiginlegri sýn í starfsmannahópnum hafa áhrif. Út frá niðurstöðunum má draga pá ályktun að bæta purfi leiðbeiningar um hlutverk aðstoðarfólks og gera kennara meðvitaða um eigið hlutverk gagnvart aðstoðarfólki. Einnig parf að bæta viðhorf til mikilvægis náms fyrir fólk með proskahömlun sem parf mikinn stuðning. Niðurstöður rannsóknarinnar benda til pess að innleiðing nálgunar um virkan stuðning í búsetupjónustu geti stutt við hlutverk aðstoðarfólks í námi fatlaðs fólks og stuðlað að pví að pað geti nýtt sér nám til jafns við aðra.

Efnisorð: Aðstoðarfólk, fólk með proskahömlun sem parf mikinn stuðning, nám, virkur stuðningur

\section{Inngangur}

Fólk með proskahömlun sem parf mikinn stuðning hefur haft takmarkaðan aðgang að námi á Íslandi í gegnum tíðina. Enn pann dag í dag hefur pað ekki fullan aðgang að námi sem stendur öðrum samfélagspegnum til boða eftir framhaldsskóla og stutt er síðan fólk með proskahömlun sem parf mikinn stuðning fékk tækifæri til símenntunar. Pað gerðist formlega pegar Pjálfunarskólinn á Kópavogshæli var stofnaður árið 1982 og síðar sköpuðust auknir möguleikar til náms með stofnun Fullorðinsfræðslu fatlaðra árið 1991. Í raun var pað pó ekki fyrr en Fjölmennt, sem var stofnuð árið 2002, hafði fengið aukið ráðgefandi hlutverk sem Fjölmennt, símenntunar- og pekkingarmiðstöð árið 2011 og flutti í nýtt húsnæði að Vínlandsleið, að tryggt var að fólk með proskahömlun 
sem parf mikinn stuðning fengi aðgang að símenntun. Fjölmennt er sjálfseignarstofnun í eigu Landssamtakanna Proskahjálpar og Öryrkjabandalags Íslands og á að pjóna öllu landinu (Fjölmennt, e.d.; María Hildibórsdóttir, 2006). Aðstæður til náms í Fjölmennt hafa breyst til batnaðar, ekki síst með auknum möguleikum fólks með proskahömlun sem parf mikinn stuðning á að hafa aðstoðarfólk frá búsetupjónustunni með sér á námskeið.

Lög og stefnumótun á Íslandi um málefni fatlaðs fólks byggja á Samningi Sameinuðu pjóðanna um réttindi fatlaðs fólks, til dæmis að geta tekið pátt í samfélaginu án aðgreiningar. Í 24. grein samningsins er fjallað um réttindi fatlaðs fólks til menntunar og par er meðal annars kveðið á um að aðildarríkin skuli tryggja „að árangursríkar, einstaklingsbundnar stuðningsaðgerðir séu boðnar fram" (Samningur Sameinuðu pjóðanna um réttindi fatlaðs fólks, 2007, 24. grein). Í lögum um pjónustu við fatlað fólk með langvarandi stuðningsparfir er skýrt sett fram að fatlað fólk eigi rétt á pjónustu og jafnframt notendastýrðri persónulegri aðstoð (NPA) til pess að geta tekið pátt í námi og samfélagi (Lög um pjónustu við fatlað fólk með langvarandi stuðningsparfir nr. 38/2018). Ljóst er að með bættri pjónustu á grundvelli samningsins og pessara laga má áætla að peim fjölgi sem geta nýtt sér aðstoðarfólk úr búsetupjónustunni í námi. Aðstoðarfólk getur gegnt lykilhlutverki í peirri pjónustu sem snýr að námi fatlaðs fólks, hvort sem um er að ræða aðstoðarfólk sem vinnur í hefðbundinni búsetupjónustu eða aðstoðarfólk sem vinnur við notendastýrða persónulega aðstoð. Petta kallar á betri skilgreiningu á hlutverki aðstoðarfólks.

Í pessari grein verður fjallað um hlutverk aðstoðarfólks í námi fólks með proskahömlun sem parf mikinn stuðning í ljósi rannsóknarverkefnis sem unnið var sem hluti af meistaranámi fyrsta höfundar í sérkennslufræðum. Viðfangsefnið hefur lítið verið rannsakað erlendis og pessi rannsókn er sú fyrsta sinnar tegundar á Íslandi. Um er að ræða eigindlega viðtalsrannsókn en pátttakendur í rannsókninni voru sex aðstoðarmenn með ólíkan bakgrunn sem höfðu reynslu af að fylgja fólki á námskeið hjá Fjölmennt. Fólkið sem naut aðstoðar peirra hafði fengið greiningu um einhverfu eða proskahömlun, tjáði sig með óhefðbundnum tjáskiptaaðferðum og purfti mikinn stuðning í daglegu lífi. Leitað er svara við eftirfarandi spurningu: „Hvernig lítur aðstoðarfólk á hlutverk sitt í námi fólks með proskahömlun sem parf mikinn stuðning?“

Fyrsti höfundur hefur unnið sem kennari hjá Fjölmennt frá árinu 2007 og hefur par af eigin raun kynnst námi fullorðins fólks með proskahömlun sem parf mikinn stuðning og í auknum mæli tekið pátt ísamstarfi við aðstoðarfólk sem fylgir fólki á námskeið pangað. Reynsla höfundar kveikti áhugann á að gera pessa rannsókn og vonast er til vonar að með henni megi skýra betur hlutverk aðstoðarfólks og par með auka möguleikana á að nýta krafta pess betur í námi fólks með proskahömlun sem parf mikinn stuðning.

\section{Bakgrunnur}

Hér verður greint frá fræðilegum undirstöðum rannsóknarinnar par sem fyrst verður fjallað um hugmyndir um gagnkvæmni í aðstoð ásamt pjónandi leiðsögn sem undanfarin ár hefur verið innleidd í pjónustukerfi stærstu sveitarfélaga hér á landi. Einnig verður fjallað um aðra nálgun í stuðningi sem hefur verið notuð í pjónustu við fatlað fólk sem parf mikinn stuðning, meðal annars í Bretlandi og Ástralíu, og kölluð er virkur stuðningur. Lítið hefur enn sem komið er verið fjallað um pessa nálgun á Íslandi. Að lokum verður greint frá nokkrum fyrri rannsóknum á starfi aðstoðarfólks.

\section{Gagnkvæmni í aðstoð}

Hugmyndir um samband aðstoðarfólks og notenda hafa á síðustu áratugum próast frá að um sé að ræða andstæða póla yfir í að lögð sé áhersla á gagnkvæm tengsl á milli aðila. Hefðbundnar hugmyndir um umönnun byggja á að peir sem purfa aðstoð séu háðir og einungis piggjandi í sambandinu. Sá sem veiti aðstoðina beri í vissum skilningi ábyrgð og pað sé einungis hann sem gefi af sér í sambandinu (Thomas, 2007). Fötlunarfræðingar á borð við Jenny Morris hafa gagnrýnt pessar hugmyndir par 
sem pær ýta undir að horft sé pannig á fatlað fólk að pað sé ófært um að taka ákvarðanir um eigið líf. Morris leggur áherslu á að hugmyndir um ósjálfstæði séu félagslega skapaðar og að pjónustukerfi sem byggir á hefðbundnum hugmyndum um umönnun hindri fatlað fólk í að rækta sjálfræði sitt (Morris, 1997). Pess vegna er lögð áhersla á að hætta purfi að nota hugtakið „umönnunaraðilar“ og nota frekar „aðstoðarfólk“ til pess að auka vald fatlaðs fólks í eigin lífi (Thomas, 2007).

Hugmyndir um gagnkvæmni í aðstoð (e. reciprocity of care) eiga meðal annars rót sína að rekja til pessarar gagnrýni en einnig til femínista sem hafa bent á að konur séu í miklum meirihluta peirra sem gegna umönnunarstörfum en í hefðbundnum hugmyndum um umönnun er ekki gert ráð fyrir gagnkvæmum tilfinningatengslum á milli umönnunaraðila og pess sem parf aðstoð (Thomas, 2007). Sameiginlegur flötur fötlunarfræðinga og femínista felst í að líta á samband aðstoðarfólks og pjónustunotenda sem fjölpætt. Viðurkenna parf gagnkvæm tengsl og gagnkvæmar parfir og pað að báðir aðilar eru háðir hvor öðrum í flóknu samspili (Walmsley, 1993; N. Watson, McKie, Hughes, Hopkins og Gregory, 2004). Fólk með proskahömlun lítur í sumum tilfellum á sig sem umönnunaraðila og sýnir oft umhyggju og væntumpykju í garð aðstoðarfólks síns (Pockney, 2006). Pví parf að breyta gamalgrónum hugmyndum um fatlað fólk og aðstoðarfólk sem einfaldar andstæður.

\section{Pjónandi leiðsögn}

Pjónandi leiðsögn (e. gentle teaching) hefur verið innleidd sem ein af peim vinnuaðferðum sem starfsfólk og stjórnendur í búsetupjónustu fatlaðs fólks í Reykjavík purfa að tileinka sér til pess að ná sem bestum árangri við innleiðingu hugmyndafræðinnar um sjálfstætt líf (Reykjavíkurborg, Velferðarsvið, 2018). Bandaríski fræðimaðurinn John J. McGee og samstarfsfélagar hans próuðu pjónandi leiðsögn sem nálgun í stuðningi við fólk með proskahömlun og hegðunarfrávik á níunda áratug síðustu aldar. Markmiðið var að finna leið til að fyrirbyggja erfiða hegðun. Ætlunin var að bjóða upp á nýjung sem væri andsvar við hagnýtri atferlisgreiningu (e. applied behavior analysis) sem var á peim tíma leiðandi í starfi með fólki sem sýndi krefjandi hegðun og var gagnrýnd fyrir að leiða oft til nauðungar og refsingar (McGee, 1992; Van de Siepkamp, McCrovitz og Vincent, 2018). Pó að lögð hefði verið áhersla á erfiða hegðun í upphafi var pó ávallt litið pannig á að hegðunin væri ekki vandamálið sem purfti að leysa heldur sá vandi sem orsakaði hegðunina, svo sem óöryggi, erfiðar tilfinningar eða ytri aðstæður. Nálgunin hefur próast yfir í að leggja áherslu á að skoða og breyta sambandi og samskiptamynstri aðstoðarfólks og einstaklinganna. Рað að fyrirbyggja erfiða hegðun verður pví jákvæð afleiðing frekar en meginmarkmiðið (Gentle Teaching, e.d.; McGee, 1992).

Markmiðið í pjónandi leiðsögn er að kenna fólki að upplifa öryggi, virðingu, umhyggju og tengsl í samskiptum við aðstoðarfólk sitt. Lögð er áhersla á að báðir aðilar upplifi sambandið sem vinskap (e. companionship) sem byggi á skilyrðislausri væntumpykju (e. unconditional relationship). Pannig einkennist sambandið milli aðstoðarfólks og einstaklingsins af gagnkvæmum tengslum (e. interdependence). Nauðsynlegt er að aðstoðarfólk hafi einlægan áhuga á samskiptum við einstaklinginn og líti svo á að pað sé skuldbundið honum. Á sama tíma mun aðstoðarfólk pví upplifa meiri ánægju og vellíðan í starfi og öðlast aukna innsýn í eigin tilfinningar og viðbrögð (Gentle Teaching, e.d.; Van de Siepkamp o.fl., 2018). Pjónandi leiðsögn er pví nátengd hugmyndum um gagnkvæmni í aðstoð.

Í pjónandi leiðsögn er einnig fjallað um hið stærra samhengi í lífi fatlaðs fólks. Litið er á samband einstaklingsins og aðstoðarfólks sem grunn pess að gera honum kleift að taka pátt í eigin lífi og hafa áhrif á eigin lífsgæði. Samkvæmt skilgreiningu forsvarsmanna pjónandi leiðsagnar er hluti af lífsgæðum fólks fólginn í að upplifa sig í tengslum við heiminn umhverfis, að geta tekið pátt í raunverulegum verkefnum daglegs lífs og að geta próað eigin hæfileika (Van de Siepkamp o.fl., 2018). Nálgunin tengist pví einnig námi og hlutverki aðstoðarfólks í tengslum við pað. Lögð hefur verið áhersla á að pjónandi leiðsögn sé ekki lausn allra vandamála og hvatt hefur verið til pess að nota nálgunina með öðrum nálgunum og aðferðum (Gentle Teaching, e.d.; McGee, 1992). 


\section{Virkur stuðningur}

Virkur stuðningur (e. active support) próaðist sem nálgun í Bretlandi á níunda áratug síðustu aldar í kjölfar pess að stórum stofnunum var lokað og nýir möguleikar til búsetu fyrir fólk með proskahömlun urðu til. Nálgunin var meðal annars hugsuð sem leið að markmiðum hugmyndafræðinnar um eðlilegt líf og frá upphafi var lögð áhersla á að auka pátttöku fatlaðs fólks í raunverulegum verkefnum í daglegu lífi sem leið til valdeflingar og aukinna lífsgæða (Toogood, Totsika, Jones og Lowe, 2016). Með nálguninni er áhersla lögð á virka og merkingarbæra pátttöku par sem val einstaklingsins er lykilatriði, dagskipulagið er eftir hans höfði og pörfum en ekki hugsað sem vinnuskipulag sem hentar aðstoðarfólkinu (Mansell, Beadle-Brown, Ashman og Ockendon, 2005). Nálgunin er talin geta haft sérstaklega jákvæð áhrif á samfélagspátttöku fólks með proskahömlun sem parf mikinn stuðning svo og pátttöku pess í peim daglegu athöfnum sem einkenna heimilislíf fólks (Mansell og Beadle-Brown, 2012; Totsika, Toogood og Hastings, 2008). Par sem áhersla er lögð á að einstaklingurinn taki pátt í öllum tilfallandi verkefnum sem tengjast heimilislífinu pá er ekki pörf á að búa til sérstök verkefni fyrir hann en fólk með proskahömlun fær oft á tíðum takmörkuð tækifæri til að ráða yfir eigin heimili (Guðrún V. Stefánsdóttir, Kristín Björnsdóttir og Ástríður Stefánsdóttir, 2014). Hvernig aðstoðarfólk vinnur hefur bein áhrif á hvort einstaklingurinn verði virkur pátttakandi í daglegum verkefnum og ákvarðanatöku um eigið líf en mikilvægt er að í viðhorfum peirra og vinnubrögðum felist sá skilningur að einstaklingurinn fái að ráða lífi sínu og heimili. Aðalmarkmið virks stuðnings er virk pátttaka með stuðningi eftir pörfum. Pó að unnið sé að pví að fólk geti gert sem mest sjálft er markmiðið ekki að pað megi ekki piggja aðstoð ef pað parf á henni að halda. Virkur stuðningur getur orðið til pess að einstaklingur geti tekið pátt í viðfangsefni sem hann annars gæti ekki unnið. Pátttakan skilar honum aukinni reynslu og tækifærum til að hafa áhrif á eigið líf (Mansell og BeadleBrown, 2012; Mansell, Elliott, Beadle-Brown, Ashman og Macdonald, 2002).

Áherslur nálgunarinnar hafa próast í tvær áttir. Í hinni upphaflegu nálgun var áhersla lögð á að samræma vinnubrögð aðstoðarfólks og fylgjast með framförum í gegnum viðamikið skipulag og nákvæmar skráningar. Hins vegar hefur verið próuð nálgun sem til aðgreiningar er oft kölluð einstaklingsmiðaður virkur stuðningur (e. person-centered active support) par sem lögð er meiri áhersla á pjónustuna í heild pó að stuðningur aðstoðarfólks í raunverulegum verkefnum sé enn pungamiðja nálgunarinnar (Toogood o.fl., 2016; Totsika o.fl., 2008). Mansell og Beadle-Brown hafa fjallað um einstaklingsmiðaðan virkan stuðning. Pau byggja á breiðum grunni hugmynda um mannréttindi og samfélag án aðgreiningar og tengja meðal annars nálgunina við markmið Samnings Sameinuðu pjóðanna um réttindi fatlaðs fólks. Lögð er áhersla á að til pess að efla sjálfræði pá purfi fólk að hafa valmöguleika og pví sé mikilvægt að hafa aðgang að stuðningi til að prófa nýja hluti og til að finna leiðir sem gera fólki kleift að velja. Pau hafa einnig haldið fram mikilvægi hins eflandi sambands (e. the enabling relationship) á milli aðstoðarfólks og fatlaðs fólks sem forsendu fyrir góðum vinnubrögðum. Hið eflandi samband byggir á tilfinningalegum tengslum og innihaldsríkum samskiptum (Mansell og Beadle-Brown, 2012). Einstaklingsmiðaður virkur stuðningur tengist pví einnig hugmyndum um gagnkvæmni í aðstoð.

Í einstaklingsmiðuðum virkum stuðningi er lögðáhersla á hinn daglega stuðning aðstoðarfólks frekar en skipulagningu og skráningar (Toogood o.fl., 2016; Totsika o.fl., 2008). Stuðningurinn felur í sér fjögur grunnatriði: Að líta skuli á hvert augnablik sem tækifæri til pátttöku, hvetja skuli til pátttöku í stuttan tíma í einu til pess að virða polmörk einstaklingsins, veita skuli aðstoð eftir pörfum til pess að tryggja að einstaklingurinn upplifi að hann hafi vald á verkefninu og hámarka skuli val og sjálfræði hans (Mansell og Beadle-Brown, 2012). Einnig er horft til hins víðara samhengis pjónustunnar. Lögð er áhersla á pjálfun starfsfólks og hlutverk stjórnenda í tengslum við hana, hugað að innleiðingu nálgunarinnar og hvernig megi viðhalda henni. Litið er pannig á að viðhorf aðstoðarfólks sé forsenda fyrir góðum vinnubrögðum en jafnframt að starfsfólk purfi að búa yfir færni og verkfærum til pess að yfirfæra viðhorf í góð vinnubrögð. Pví er mikilvægt að huga jafnt að viðhorfum og færni aðstoðarfólks (Beadle-Brown o.fl., 2014; Mansell og Beadle-Brown, 2012). 


\section{Fyrri rannsóknir}

Lítið hefur verið fjallað um líf fólks með proskahömlun sem parf mikinn stuðning í rannsóknum. Hlutverk aðstoðarfólks fatlaðs fólks hefur aðallega verið rannsakað í tengslum við pjónustu við fötluð börn í skóla eða við fullorðið fatlað fólk á heimili pess (Chopra o.fl., 2004; Sigurbjörg J. Helgadóttir og Hildur Björk Svavarsdóttir, 2006; Snæfríður Póra Egilson og Rannveig Traustadóttir, 2009; Dalton og Sweeney, 2011; Windley og Chapman, 2010; Pórunn Kjartansdóttir, 2016). Íslenskar rannsóknir sem beina sjónum að aðstoðarfólki sem starfar með fólki með proskahömlun sem parf mikinn stuðning eru einnig fáar. Niðurstöður peirra rannsókna sýna meðal annars fram á að aðstoðarfólk fær oft litlar upplýsingar um hlutverk sitt og skyldur og að viðhorf aðstoðarfólks getur ýmist stuðlað að eða verið hindrun í að auka lífsgæði, pátttöku og sjálfræði hjá peim sem pað aðstoðar (Guðný Jónsdóttir og Snæfríður P. Egilson, 2013; Guðrún V. Stefánsdóttir, 2015). Auk pess benda Guðný og Snæfríður (2013) á hvernig mikil starfsmannavelta og mannekla hefur áhrif á pá aðstoð sem mögulegt er að veita en aðstoðarfólkið fær hvorki nægilega pjálfun né nær að kynnast peim sem pað á að aðstoða pegar pað stoppar stutt við í starfi. Pegar viðhorf aðstoðarfólks hefur áhrif á vinnubrögð pess er mikilvægt að pað fái viðeigandi fræðslu. Guðrún (2015) skoðaði sérstaklega hvernig hægt væri að stuðla að auknu sjálfræði meðal fólks með proskahömlun sem parf mikinn stuðning. Hún komst að peirri niðurstöðu að aðstoðarfólkið pyrfti að hafa skilning á hvernig hægt væri að aðstoða fólkið við að taka ákvarðanir og pyrfti par af leiðandi fræðslu og stuðning í starfi.

Svipaðar niðurstöður má sjá í erlendum rannsóknum. Í breskri rannsókn frá 2011 rannsökuðu Dalton og Sweeney reynslu og viðhorf aðstoðarfólks til pess að aðstoða einstaklinga sem bjuggu í búsetukjarna fyrir fólk með proskahömlun við að tjá sig. Í peirri rannsókn kom meðal annars fram að aðstoðarfólk upplifði oft að pað hefði ekki nægilega pekkingu eða færni til að veita pessa aðstoð enda kvaðst meirihluti pátttakenda í rannsókninni ekki hafa fengið neina pjálfun í notkun óhefðbundinna tjáskiptaaðferða. Stór hluti peirra nefndi einnig að nauðsynleg hjálpargögn eða tæki til pess að auðvelda einstaklingunum að tjá sig væru yfirleitt ekki til staðar (Dalton og Sweeney, 2011). Joanne Watson kannaði árið 2016 í Ástralíu hvernig hægt væri að stuðla að pví í námi að fólk sem notaði óhefðbundnar tjáskiptaaðferðir gæti tjáð vilja sinn og tekið ákvarðanir um eigið líf með aðstoð frá öðrum (e. supported decision-making). Í niðurstöðum hennar kom fram að hlutverk aðstoðarfólks og kennara og samstarf peirra á milli væri mikilvægt pegar unnið væri að markmiðum um valdeflingu, pátttöku og aukin lífsgæði (J. Watson, 2016).

Umfjöllun um hlutverk aðstoðarfólks fatlaðra nemenda í íslensku skólakerfi er takmörkuð og snýr að mestu leyti að stuðningsfulltrúum á grunnskólastiginu. Ítarleg úttekt var gerð á námi grunnskólanemenda með proskahömlun árið 2007 og sýndi hún að peir nemendur sem purftu mestan stuðning í námi vörðu mestum tíma með ófaglærðu starfsfólki (Gretar L. Marinósson, 2007). Í úttekt á starfi stuðningsfulltrúa í grunnskólum Reykjavíkurborgar kom í ljós að eingöngu $5 \%$ peirra höfðu lokið háskólanámi en skortur á fagpekkingu getur haft áhrif á hvernig tekst til við að koma til móts við parfir nemenda sem purfa stuðning í námi (Sigurbjörg J. Helgadóttir og Hildur Björk Svavarsdóttir, 2006). Snæfríður Póra Egilson og Rannveig Traustadóttir (2009) hafa einnig bent á að hlutverk stuðningsfulltrúa sé oft óljóst og illa skilgreint. Niðurstöður Snæfríðar og Rannveigar samræmast vel alpjóðlegum rannsóknum á sviðinu sem benda til pess að skilgreina purfi betur hlutverk og ábyrgð aðstoðarfólks í námi fatlaðra nemenda (Chopra o.fl., 2004; Giangreco og Doyle, 2007). Enn fremur sýna niðurstöður meistaraverkefnis Pórunnar Kjartansdóttur (2016) að kennarar og stjórnendur telja hlutverk stuðningsfulltrúa mikilvægt við framkvæmd stefnunnar um skóla án aðgreiningar. Pá sé kennarinn í lykilhlutverki og undir honum komið hversu vel tekst að nýta stuðningsfulltrúann við að veita nemendum námsstuðning.

Í rannsókn sem Chopra og samstarfsfélagar gerðu í Bandaríkjunum árið 2004 á hlutverki stuðningsfulltrúa fatlaðra barna í skóla kom fram að peir gætu gegnt mikilvægu hlutverki sem tengiliðir milli mismunandi aðila í námsumhverfinu og að ýmsar hindranir gætu staðið í vegi fyrir að peir gætu sinnt hlutverki sínu. Hindranirnar snerust meðal annars um samskipti við kennara og stjórnendur og um skort á skýrri skilgreiningu á hlutverki stuðningsfulltrúanna (Chopra o.fl., 2004). Á sama hátt kom fram í rannsókn sem Windley og Chapman gerðu í Bretlandi árið 2010 
á hlutverki aðstoðarfólks á heimili fatlaðs fólks að pörf væri á að stjórnendur leiðbeindu starfsfólki meira, miðluðu skýrari sýn og sinntu betur eftirfylgni. Aðstoðarfólk sem tók pátt í rannsókninni kvaðst einnig hafa mismikið sjálfstraust til að segja öðrum til í starfi og vildi pví að stjórnendur tækju pað verkefni að sér (Windley og Chapman, 2010).

Nám háskólanemenda með proskahömlun hefur fengið aukna athygli rannsakenda á undanförnum misserum en pað eru yfirleitt nemendur sem purfa minni stuðning í daglegu lífi og langflestir tjá sig með töluðu máli (O’Brien, Bonati, Gadow og Slee, 2018). Guðrún V. Stefánsdóttir og Kristín Björnsdóttir (2018) fjölluðu um nemendur í starfstengdu diplómanámi fyrir nemendur með proskahömlun við Háskóla Íslands og hvernig samnemendur peirra veittu peim mikilvægan stuðning, bæði í námi og félagslífi. Hlutverk samnemenda sem mentorar eða aðstoðarmenn diplómunema er talsvert ólíkt hlutverki formlegs aðstoðarfólks par sem um jafningjasamband er að ræða og ætti frekar að vera skilgreint sem samstarf heldur en aðstoð. Pörf er á frekari rannsóknum á hlutverki aðstoðarfólks, á öllum skólastigum, í námi fólks með proskahömlun sem parf mikinn stuðning í peim tilgangi að skilgreina hlutverk aðstoðarfólks í námi betur og tryggja pannig að nemendur fái stuðning við hæfi.

\section{Framkvæmd}

Rannsóknin er eigindleg en slíkar rannsóknaraðferðir eru ákjósanlegar pegar fengist er við samskipti í félagslegum aðstæðum og pegar reynt er að fá upplýsingar um hvernig fólk upplifir sig í peim aðstæðum (Lichtman, 2013). Í pessu tilfelli var leitað upplýsinga um hvernig aðstoðarfólk upplifir sig í peim félagslegu aðstæðum sem skapast í tengslum við nám pess notanda sem pað aðstoðar. Hér á eftir verður greint nánar frá pátttakendum rannsóknarinnar, gagnaöflun og gagnagreiningu ásamt peim siðferðilegu atriðum sem hafa purfti í huga við framkvæmd rannsóknarinnar.

Í almennri umfjöllun um fullorðið fólk sem sækir nám á símenntunarstöðvum landsins er yfirleitt notað orðið pátttakendur en til pess að forðast misskilning verður fólkið sem fær stuðning kallað „notendur“ en pátttakendur í rannsókninni verða kallaðir „viðmælendur“.

\section{Pátttakendur}

Pátttakendur í rannsókninni voru sex aðstoðarmenn sem höfðu að minnsta kosti árs reynslu af að fylgja notendum, sem falla undir skilgreiningu rannsóknarinnar, á námskeið hjá Fjölmennt. Notað var markmiðsúrtak (e. purposive sample) par sem leitast var við að pátttakendur gætu veitt miklar upplýsingar um reynslu og viðhorf sem tengdust viðfangsefninu. Slíkt úrtak er algengt í eigindlegum rannsóknum par sem markmiðið er að draga fram sýn fólks sem hefur reynslu af ákveðnu fyrirbæri (Braun og Clarke, 2013). Fyrsti höfundur notaði tengsl sín við starfsfólk í búsetupjónustunni til að nálgast pátttakendur og fékk einnig ábendingar frá samkennurum í starfi sínu hjá Fjölmennt. Einnig var stuðst við fjölbreytniúrtak (e. maximum variation sample) par sem reynt var að endurspegla fjölbreytileika meðal aðstoðarmanna (Flick, 2006).

Í hópi pátttakenda var jafnt hlutfall karla og kvenna og spannaði starfsreynsla peirra frá einu upp í tíu ár. Pátttakendur höfðu ólíkan menntunarlegan bakgrunn en tveir voru með proskapjálfamenntun, einn með starfsmenntun á öðru sviði sem nýttist honum ekki í starfi og prír með enga formlega menntun. Peir störfuðu í ólíkum pjónustukerfum og eftir ólíku pjónustuskipulagi. Fimm störfuðu sem aðstoðarmenn í mismunandi búsetukjörnum á höfuðborgarsvæðinu, par af var einn einnig deildarstjóri. Einn pátttakandi starfaði sem aðstoðarmaður fyrir notanda með pjónustu í anda notendastýrðrar persónulegrar aðstoðar (NPA). Pátttakendur höfðu par að auki ólíka reynslu af námi notenda hjá Fjölmennt og samstarfi við kennara. 


\section{Gagnaöflun og gagnagreining}

Í rannsókninni voru tekin hálfopin viðtöl við pátttakendur rannsóknarinnar, eitt viðtal við hvern pátttakanda sem tók að jafnaði 45 mínútur, á tímabilinu mars 2018 til janúar 2019. Sú aðferð var talin henta vel par sem markmiðið var að öðlast skilning á sýn aðstoðarfólks á eigið hlutverk í námi notenda. Hálfopin viðtöl eru algengasta rannsóknaraðferð í eigindlegum rannsóknum og henta vel til að öðlast djúpan skilning á reynslu og viðhorfum fólks (Braun og Clarke, 2013; Lichtman, 2013). Í viðtölunum var sjónum beint að aðstoðarfólkinu, upplifun pess og reynslu. Aðstoðarfólkið var meðal annars spurt hver tilgangurinn væri með námi notenda í Fjölmennt og hvernig pað hefði áhrif á líf peirra. Viðmælendur voru beðnir um að lýsa hlutverki sínu í námi notenda og samskiptum og samvinnu við kennara og annað starfsfólk. Peir voru einnig beðnir um að meta hvernig námið hefði áhrif á sjálfstæði og tjáningu notenda. Í eigindlegum rannsóknum er algengt að hefja greiningu gagna áður en gagnaöflun lýkur og nota gagnagreininguna markvisst til að próa rannsóknina (Braun og Clarke, 2013). Gagnagreining hófst oftast strax við afritun. Gögnin voru greind með pemagreiningu par sem markmiðð var að finna mynstur sem endurtæki sig pvert á gögnin. Stuðst var við leiðbeiningar Braun og Clarke (2013) um samtals sex greiningarprep.

\section{Siðferðileg álitamál}

Sá hópur fólks sem sækir nám hjá Fjölmennt og hefur með sér aðstoðarfólk er tiltölulega fámennur og aðstæður pess í námi og daglegu lífi oft mjög sérhæfðar og par með auðpekkjanlegar fyrir pá sem pekkja eitthvað til. Pví purfti að huga sérstaklega að pví að tryggja nafnleynd viðmælenda í rannsókninni sem og notenda sem tengjast peim. Reynt var eftir fremsta megni að tryggja nafnleynd með pví að nota tilbúin nöfn fyrir persónur og staðarheiti sem fram koma í gögnunum að undanskildu nafninu á Fjölmennt par sem vitað er að viðmælendur hafa fylgt notendum á námskeið pangað. Einnig var lýsingum viðmælenda á starfsaðstæðum og aðstæðum notenda í sumum tilfellum breytt til pess að tryggja nafnleynd og halda trúnað. Í einstaka tilfelli var gripið til pess ráðs að breyta kyni fólks sem lýst var í gögnunum. Pví er ekki hægt að draga neinar ályktanir tengdar kyni eða kynbundnum páttum út frá niðurstöðum pessarar rannsóknar.

Mikilvægt siðferðilegt atriði sem parf að hafa að leiðarljósi í eigindlegum rannsóknum er að huga vel að tengslum rannsakanda og viðmælenda. Huga parf að samskiptum við viðmælendur og hvernig viðhorf rannsakanda getur haft áhrif á hvernig hann spyr og hvernig hann vinnur úr gögnunum (Ástríður Stefánsdóttir, 2013). Petta á ekki síst við í rannsókninni sem hér um ræðir par sem fyrsti höfundur var að rannsaka eigin starfsvettvang. Huga purfti sérstaklega að valdastöðu rannsakanda og var pess gætt að bjóða einungis aðstoðarfólki pátttöku í rannsókninni sem fyrsti höfundur hafði ekki verið í samstarfi við sem kennari í Fjölmennt. Einnig var viðmælendum boðið upp á tvo valkosti varðandi hvar viðtal ætti að fara fram auk pess að stinga sjálfir upp á staðsetningu. Öll viðtöl nema eitt fóru fram í húsnæði Fjölmenntar. Bakgrunnur fyrsta höfundar sem kennari hjá Fjölmennt gæti hafa haft áhrif á rannsóknina par sem reynsla hans af samstarfi við aðstoðarfólk í námi notenda hefur mótað hugmyndir hans um hvernig hann vill hafa samstarfið. Hann var pó mjög meðvitaður um pessi áhrif við afritun og greiningu gagnanna og reyndi pá að nota pau markvisst til pess að koma auga á sýn viðmælenda.

Viðmælendur fengu skjal með upplýsingum um rannsóknina og var upplýsts sampykkis frá hverjum og einum viðmælanda aflað áður en viðtal hófst.

\section{Niðurstöður}

Hér verður gerð grein fyrir niðurstöðum rannsóknarinnar í fimm köflum sem ætlað er að svara rannsóknarspurningunni: „Hvernig lítur aðstoðarfólk á hlutverk sitt í námi fólks með proskahömlun sem parf mikinn stuðning? 


\section{Aðstoðarfólkið mótar sjálft hlutverk sitt}

Viðmælendur, sem allir höfðu reynslu af pví að fylgja notendum á námskeið hjá Fjölmennt, lýstu yfir að peir sinntu mjög ólíkum hlutverkum, allt eftir pví um hvaða námskeið var að ræða og hverjar stuðningsparfir notanda voru. Peir sögðust almennt hafa fengið litlar sem engar leiðbeiningar um hlutverk sitt í námi notenda, hvort sem var frá kennurum Fjölmenntar eða frá yfirmönnum sínum í búsetupjónustunni. Fyrri rannsóknir hafa sýnt að peir sem aðstoða fólk með proskahömlun sem parf mikinn stuðning, annaðhvort sem stuðningsfulltrúar í skóla eða sem aðstoðarfólk á heimili pess, fá oft litlar upplýsingar um hlutverk sitt og skyldur (Chopra o.fl., 2004; Giangreco og Doyle, 2007; Guðný Jónsdóttir og Snæfríður P. Egilson, 2013; Snæfríður Póra Egilson og Rannveig Traustadóttir, 2009). Í pessari rannsókn kemur skýrt fram að svo er einnig tilfellið með aðstoðarfólk í námi fullorðinna notenda. Viðmælendur í rannsókninni lýstu pví pannig að pegar peir byrjuðu að fara með notendum á námskeið hjá Fjölmennt pá hefði pað verið eins og að vera hent út í djúpu laugina og peir hefðu purft að bjarga sér sjálfir. Berta orðaði pað svo: „Рað var bara: „Рú ferð með honum og pú finnur út úr pvi“" [hlær]. Verður bara að spila pað paðan." Pegar aðstoðarfólk fær litlar leiðbeiningar um hvert hlutverk pess er í námi notenda kemur ekki á óvart að mjög misjafnt er hvernig pað lítur á eigið hlutverk í kennslustundum.

\section{Prjú ólík hlutverk}

Greina má prjú ólík hlutverk aðstoðarfólks í lýsingum viðmælenda, pau eru „milliliðurinn“, „stuðningsaðilinn“ og „hinn hlutlausi fylgdarmaður“.

\section{Milliliðurinn}

Hlutverk milliliðsins byggir á að aðstoðarmaðurinn pekki notandann betur en kennarinn og hafi par af leiðandi dýpri skilning á pörfum hans og tjáskiptamáta. Milliliðurinn leggur áherslu á að túlka og hann getur purft að túlka í báðar áttir. Stundum parf að túlka fyrir kennarann hvað notandi er að tjá, til dæmis með hljóðum, svipbrigðum eða hegðun. Stundum parf að túlka fyrir notandann hvað kennarinn segir eða vill að hann geri með pví að einfalda skilaboðin eða koma peim yfir á annað form. Snorri lýsti hlutverki milliliðsins svo:

Ehm, í rauninni, erum pínu svona milliliður á milli peirra og Fjölmenntar eða pannig. Svona kannski ef pað er eitthvað sem að ... Af pví við erum náttúrlega með peim á hverjum degi og pekkjum svo vel, pú veist, allt petta daglega, að pá kannski ef við purfum einhvern veginn að túlka yfir.

Milliliðurinn leggur einnig áherslu á að leiðbeina kennaranum varðandi hvernig notanda finnst best að gera hlutina. Hann getur par að auki veitt kennaranum mikilvægar upplýsingar um reynslu notanda sem tengist viðfangsefni kennslustundarinnar og sem getur skipt máli fyrir námið. Magnús lýsti mismunandi verkefnum milliliðsins á eftirfarandi hátt:

Mér finnst svona starf mitt búið að vera dálítið í, hérna, að kenna samskiptin: „Hvernig, hvernig tjáir pessi sig? Hvað pýðir petta? Hvað er hann að segja núna?“ ... Og svo hefur líka starf mitt verið í pví að, að hérna, hvernig er best að vinna verkin? Eh, til dæmis, pað hentar ekki honum að standa við borð allan tímann.

Рað gerir miklar kröfur til aðstoðarfólksins að sinna hlutverki milliliðsins. Aðstoðarfólk parf að hafa góða færni í að lesa í tjáningu notanda og eiga samskipti við hann ásamt að meta hvaða upplýsingar kennarinn parf á að halda. Segja má að milliliðurinn vinni jafnt með notandanum og kennaranum og hann hefur pað markmið að auðvelda samskipti og samstarf peirra á milli. 


\section{Stuðningsaðilinn}

Stuðningsaðilinn aftur á móti er aðallega tengdur notandanum og er fyrst og fremst á staðnum til að styðja hann og veita honum öryggi. Petta getur verið mjög mikilvægt atriði í námi fólks með proskahömlun sem parf mikinn stuðning par sem pað upplifir oft mikið óöryggi í nýjum aðstæðum og innan um fólk sem pað pekkir ekki. Náið samband notanda og aðstoðarfólks er undirstöðuatriði pess að stuðningsaðilinn geti sinnt hlutverki sínu. Sambandið parf að byggjast á trausti og væntumpykju til pess að notandinn finni fyrir öryggi með aðstoðarfólki sínu í krefjandi aðstæðum. Berta leit á sig sem stuðningsaðila og lýsti hlutverki sínu á pennan veg:

Mér finnst svona, ég upplifi meira eins og starfið mitt bara ... Að hann viti að ég sé hérna. Svona öryggisnet fyrir hann. Pú veist, auðvitað eru svona eins og pau sem eru með námskeiðin meira að aðstoða hann og svona. En meira eiginlega, já, svona stuðningsnet fyrir hann, að hann viti að ég sit við hliðina á honum og er parna. Sérstaklega af pví að hann á svolítið erfitt með nýtt fólk og nýjar aðstæður.

Stuðningsaðilinn getur aðstoðað notanda við að vinna krefjandi verkefni í kennslustundinni, svo sem verkefni sem reyna á að notandi tjái skoðun sína. Pað auðveldar notanda að vinna slík verkefni með einhverjum sem hann treystir og pekkir vel. Milliliðurinn og stuðningsaðilinn geta átt margt sameiginlegt en aðalmunurinn er pó sá að stuðningsaðilinn er, ólíkt milliliðnum, fyrst og fremst til staðar fyrir notandann til pess að veita honum öryggi og styðja hann pannig í náminu.

\section{Hinn hlutlausi fylgdarmaður}

Hinn hlutlausi fylgdarmaður er hvorki tengdur notandanum né kennaranum í kennslustundinni. Hans hlutverk tengist lítið námi notanda meðan á kennslu stendur. Hann sér um að koma notanda á staðinn og aðstoðar hann par aðallega við athafnir daglegs lífs. Stundum bíður hann fyrir utan kennslustofuna á meðan kennslustundin fer fram. Ef hann er inni í kennslustofunni er pað oftast til að grípa inn í ef öryggi kennarans er ógnað vegna hegðunar notanda. Pví má segja að andstætt við stuðningsaðilann er hinn hlutlausi fylgdarmaður á staðnum til pess að veita kennaranum öryggi en ekki notandanum. Aðalsteinn fellur undir pessa skilgreiningu og lýsti hlutverki sínu á eftirfarandi hátt:

Öh, sko, mitt hlutverk er nú bara aðallega að mæta á staðinn með karlinn og sitja og fylgjast með pegar hann er í matreiðslunni ... Ég myndi nú bara svona sennilega kallast bara fylgdarmaður af pví að ég er eiginlega ekki að gera neitt annað en að fylgja, keyra hann hingað upp eftir og, og já, svo svona stundum, pú veist, parf hann að fara fram á klósettið og svona og pá fer ég með honum.

Nokkrir viðmælendur lýstu pví sem mikilvægum hluta af sínu hlutverki að grípa inn í ef notandi sýndi á einhvern hátt óviðeigandi hegðun. Aðalsteinn orðaði petta skýrt:

Рað hefur, pað hafa komið upp móment par sem að hefur purft að svona hálfpartinn að grípa dálítið harkalega inn í svo að hann meiði ekki einhvern eða, pú veist ... Já já, maður er alltaf, maður er alltaf svona á tánum pegar Grétar er annars vegar, sko, pó að pað sé algjör undantekning að hann sé með eitthvað vesen hérna, sko.

Ólíkt milliliðnum og stuðningsaðilanum pá virðist hinn hlutlausi fylgdarmaður ekki horfa á pað sem hugsanlega liggur að baki hegðuninni. Hann bregst einungis við pegar hegðunin fer að trufla kennslustundina. Að pví leytinu til má segja að hann sé aðallega á staðnum til að sjá til pess að kennslan geti farið fram án truflunar. Hann tekur ekki virkan pátt í kennslustundinni með pví að túlka hegðun notanda sem tjáningu fyrir kennarann eins og milliliðurinn hefði gert eða með pví að ganga inn í aðstæðurnar og veita notanda öryggi til pess að reyna að koma í veg fyrir erfiða hegðun líkt og stuðningsaðilinn hefði gert. Bandarísk rannsókn frá 2004 gaf vísbendingu um að aðstoðarfólk gæti gegnt mikilvægu hlutverki sem tengiliðir milli aðila í námsumhverfinu (Chopra 
o.fl., 2004). Milliliðurinn og stuðningsaðilinn eru einmitt dæmi um slíka tengiliði á meðan hinn hlutlausi fylgdarmaður sér sig ekki sem hluta af námsumhverfinu og getur pví ekki verið tengiliður í pví samhengi.

ÁMynd 1 eru sýnd helstu einkenni hlutverkanna priggja sem hér hefur verið lýst. Á meðan milliliðurinn tengist bæði kennaranum og notandanum pá tengist stuðningsaðilinn aðallega notandanum, en báðir geta peir aðstoðað notanda við að taka pátt í náminu. Hinn hlutlausi fylgdarmaður tengist hins vegar hvorki kennaranum né notandanum og lítur ekki á sig sem hluta af námsumhverfinu. Pað gerir honum erfitt fyrir að sinna viðeigandi hlutverki í námi notanda.

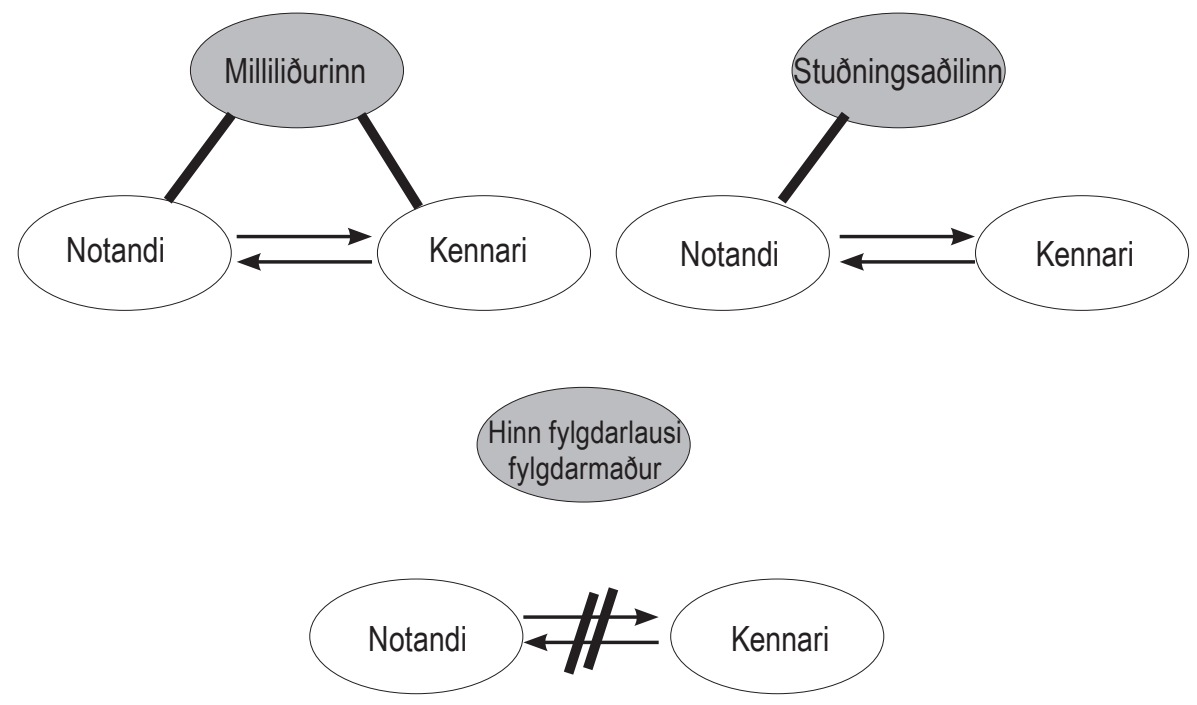

Mynd 1. Prjú ólík hlutverk aðstoðarfólks í námi notenda.

\section{Ólík sýn á hlutverk kennarans}

Hvernig aðstoðarfólk lítur á hlutverk sitt í kennslustundum tengist hvernig pað lítur á hlutverk kennarans. Hægt er að flokka lýsingar viðmælenda á hlutverki kennarans í prjú ólík viðhorf sem hafa áhrif á hvernig aðstoðarfólk mótar hlutverk sitt í náminu: Kennarinn sem jafningi, kennarinn sem fyrirmynd og kennarinn sem stjórnandi.

\section{Kennarinn sem jafningi}

Pegar litið er á kennarann sem jafningja er áhersla lögð á að kennari og aðstoðarfólk vinni saman í kennslustofunni, að aðstoðarfólkið geti leiðbeint kennaranum og veitt honum mikilvægar upplýsingar um notandann. Pessi sýn tengist pví beint hlutverki aðstoðarfólks sem milliliðs. Í einstaka tilviki getur samstarfið á milli notanda, kennara og aðstoðarfólks orðið pað náið að allir vinni saman sem jafningjar en pá skiptir einnig máli að kennarinn vilji samstarf og sýni pað með framkomu sinni við aðstoðarfólkið. Námið verður samvinna milli allra priggja. Erna lýsti pví á pennan hátt:

Stundum langar hann kannski að horfa á myndir eða hann vill spila tölvuleik eða eitthvað. Pá horfum við alltaf, eins og, við prjú, ég sem aðstoðarmaður og kennarinn og hann sjálfur, við horfum alltaf saman sem hópur, pú veist. Eins og, pað er eins og pað er einhver samvinna eða samstarf á milli okkar, pannig að við erum eins og pátttakendur í pví sem hann gerir.

Sýn aðstoðarfólks á kennarann sem jafningja getur ýtt undir að pað taki að sér hlutverk milliliðsins. Рað virðist einnig geta jafnað út pann valdamun sem oftast er á milli nemenda og kennara og stuðlað að pví að notandi, kennari og aðstoðarfólk vinni saman sem jafningjar. 
Kennarinn sem fyrirmynd: Pegar litið er á kennarann sem fyrirmynd er aðstoðarfólk líklegt til að vera meðvitað um hvað pað getur sjálft lært. Líta má á pað sem aðstoðarfólkið lærir sem mikilvægan hluta af námi notanda sem meðal annars getur hjálpað honum að nýta sér námið í daglegu lífi. Hlutverk kennarans sem fyrirmynd er pví mjög mikilvægt í pessu sambandi. Hann getur verið fyrirmynd í að finna nýjar leiðir til að eiga samskipti við notanda og gert aðstoðarfólkinu pannig betur kleift að taka sér hlutverk milliliðsins, eða eins og Erna lýsti pví: „Pannig að í pessu ferli, pegar ég er með pessum nemanda, pá fæ ég líka nýja pekkingu: Hvernig á að tækla pessar aðstæður? Hvernig get ég, hvernig get ég átt betri samskipti við hann?" Kennarinn getur einnig verið fyrirmynd að ákveðnum vinnubrögðum sem hægt er að yfirfæra á daglegt líf notanda. Erna lýsti pví svo:

Oftast er pað eitthvað sem ég bara svona sé og síðan vinn áfram með. Eins og ég lærði af pessu og síðan segi ég: „Ókei, ég ætla að prófa petta heima líka. Ef pað virkar í skólanum pá hlýtur petta að virka heima líka."

Kennarinn getur pví verið góð fyrirmynd og sýnt fordæmi í kennslustundinni. Hann getur einnig sent ákveðin skilaboð með viðbrögðum sínum sem síðan geta haft áhrif á hvaða hlutverk aðstoðarfólk tekur að sér í kennslustundinni.

Snorri lýsti aðstæðum par sem kennarinn sýndi skýrt með viðbrögðum sínum að hann ætlaðist til pess að aðstoðarfólkið gripi inn í án pess að pað hefði verið rætt neitt sérstaklega: „Bara, pú veist, petta voru einhverjar svona líkamlegar aðstæður og kennarinn bara færði sig frá pví og, og bara svona leyfði pví að klárast. Svo hélt tíminn bara áfram, sko.“

Í pessu tilfelli urðu viðbrögð kennarans til pess að aðstoðarfólkið tók að sér hlutverk hins hlutlausa fylgdarmanns. Ef kennarinn hefði brugðist öðruvísi við hefði hann getað nýtt sér stöðu sína sem fyrirmynd, jafnvel stuðlað að pví að aðstoðarfólkið horfði á sig sem stuðningsaðila og myndi grípa öðruvísi inn í. Stuðningsaðilinn gæti komið í veg fyrir að pessar aðstæður kæmu upp með pví að veita notanda öryggi og leiðbeina kennaranum.

\section{Kennarinn sem stjórnandi}

Pegar aðstoðarfólk lítur á kennarann sem stjórnanda í kennslustundinni er pað kennarans að ráða ferðinni og aðstoðarmaðurinn leggur ekki frekar mat á pað sem par fer fram. Pessi sýn á kennarann tengist beint hlutverki aðstoðarfólks sem hins hlutlausa fylgdarmanns. Aðalsteinn lýsti pví skýrt hvernig hann horfði á kennarann sem stjórnanda í kennslustundinni og hvernig hann varð par af leiðandi hlutlaus fylgdarmaður:

Hún tekur bara á móti okkur og svo fara pau bara í, í prógrammið, sko ... Ég mæti bara og sest í stólinn og fylgist með, og pað hefur bara verið pannig, og ég held pað purfi ekki að vera neitt öðruvísi, sko.

Hér skiptir framkoma kennarans aftur máli, hvort hann býður upp á samstarf eða ekki. Einnig getur komið fyrir að milliliðurinn eða stuðningsaðilinn líti á kennarann á pennan hátt og veigri sér við að grípa inn í kennslustundina fyrir hönd notanda til pess að trufla ekki kennarann. Pá hefur kennarinn sjálfur gefið pað í skyn að hann sé stjórnandi kennslustundarinnar. Eins og Snorri orðaði pað: „Einhvern veginn finnst okkur kannski eins og við séum að stíga yfir einhver mörk ef við erum eitthvað svona, pú veist að grípa fram í eða pannig." Pað er ákveðinn vandi fólginn í að aðstoðarfólk líti á kennarann sem stjórnanda. Рað ýtir undir að aðstoðarfólk fari í hlutverk hins hlutlausa fylgdarmanns frekar en milliliðsins eða stuðningsaðilans. Einnig getur pað komið í veg fyrir að aðstoðarfólk grípi inn í pótt pað telji pörf á, til dæmis til að leiðbeina kennaranum um hvernig notanda finnst best að gera hlutina.

Á Mynd 2 er sýnt hvernig ólík sýn á hlutverk kennarans getur leitt til pess að aðstoðarfólk taki að sér ólík hlutverk eins og hér hefur verið lýst. 

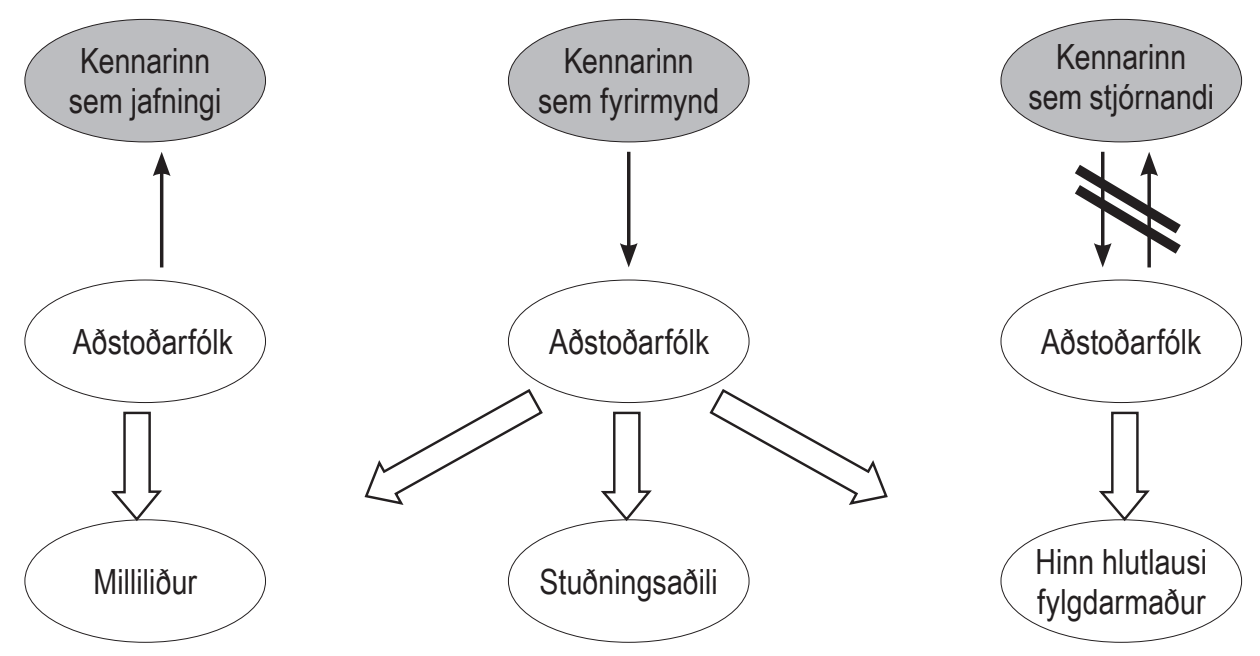

Mynd 2. Ólík sýn á hlutverk kennarans og áhrif hennar á hlutverk aðstoðarfólks.

\section{Áhrifapættir}

Niðurstöður rannsóknarinnar sýna að viðmælendurnir deildu ekki sameiginlegri sýn á hlutverk aðstoðarfólks í námi notenda. Eins og fram hefur komið pá fengu peir takmarkaða leiðsögn og purftu að finna sjálfir út hvert hlutverk peirra væri. Í peim tilfellum par sem margir komu að pví að aðstoða notanda pá var ekki heldur sameiginleg sýn á hlutverk peirra innan starfsmannahópsins. Ýmsir pættir höfðu hafa áhrif á hvernig aðstoðarfólkið skilgreindi og mótaði hlutverk sitt en skipulag búsetupjónustunnar í formi vaktafyrirkomulags, fjölda starfsmanna og stjórnskipunar var meðal pess sem viðmælendurnir nefndu sem hindrun varðandi samstarf starfsmanna um nám notenda. Mansell og Beadle-Brown (2012) hafa bent á að ef stuðla eigi að virkum stuðningi við notendur purfi að tryggja að ytra skipulag pjónustunnar styðji við samstarf aðstoðarfólks og viðurkenna purfi mikilvægi hlutverks stjórnenda í að stuðla að sameiginlegri sýn sem geti leitt starfsmannahópinn áfram í samræmdum vinnubrögðum. Pessi skortur á sameiginlegri sýn kemur í veg fyrir að notendur geti nýtt sér nám í daglegu lífi. Рað parf að vera vettvangur fyrir samstarf og aðstoðarfólk parf að hafa svigrúm og tækifæri til að ræða saman. Líney lýsti hvernig erfiðar aðstæður sem sköpuðust á vaktaskiptum vegna mikils fjölda starfsmanna urðu til pess að tækifæri gafst ekki alltaf til að ræða saman:

Svo er bara rosalega mikið af starfsmönnum pannig að pað er mikið flæði, og svo er kannski, einhver parf að fara og svo er einhver að taka við og svo kemur manneskjan sem er að fara á vaktina og, pú veist, petta er svona oft smá svona kaos, finnst mér, á vaktaskiptum.

Skipulag stjórnunar, meðal annars í formi fjölda prepa í skipuriti pjónustunnar, getur einnig hindrað samstarf aðstoðarfólks vegna náms notenda. Helmingur viðmælenda starfar í búsetupjónustu par sem teymisstjórar eru millistjórnendur. Hjá viðmælanda sem starfar í pjónustu í anda NPA er yfiraðstoðarmaður tengiliður á milli aðstoðarfólks og foreldra sem síðan sjá um aðalsamskiptin varðandi námið hjá Fjölmennt. Snorri hrósaði fyrirkomulaginu með teymisstjóra í pjónustunni par sem hann vann:

Par var kominn forstöðumaður með reynslu og pað var valið inn pessa teymisstjóra sem eru síðan öll bara, pú veist, bara frábærir í sínu starfi. Og mér finnst svo flott að, pú veist, forstöðumaðurinn hann sér svona um heildina, hann pekkir ógeðslega mikið almennt og hefur mikla reynslu hér og par, en svo teymisstjórarnir að peir pekkja sitt fólk bara inn og út, sko. 
Viðmælendurnir töldu ábyrgð og hlutverk teymisstjóra í búsetupjónustu mikla, sérstaklega par sem margir starfsmenn koma að pví að aðstoða notanda. Oft sé pað pannig að starfsmannahópurinn sé stór, margir í hlutastarfi í litlu starfshlutfalli og mannekla viðvarandi. Pá er mikilvægt að teymisstjórarnir miðli upplýsingum milli peirra aðila sem að námi notenda koma. Aðstæðurnar sem viðmælendur lýstu eru sambærilegar við niðurstöður íslenskra rannsókna á bjónustu við fatlað fólk sem parf mikinn stuðning en mannekla og mikil starfsmannavelta eru par algengt vandamál (Guðný Jónsdóttir og Snæfriłður P. Egilson, 2013; Guðrún V. Stefánsdóttir, 2015).

\section{Viðhorf til starfsins}

Lítið virðist vera rætt um nám notenda á starfsmannafundum í búsetupjónustunni en pað hefur einnig áhrif á að ekki ríkir sameiginleg sýn í starfsmannahópnum. Mansell og Beadle-Brown (2012) leggja áherslu á mikilvægi pess að stjórnendur leggi sig fram við að hafa áhrif á umræðuna með pví að miðla skýrri sýn og gefa skýr fyrirmæli á starfsmannafundum. Með markvissri fræðslu geta stjórnendur haft áhrif á starfsmannahópinn, viðhorf aðstoðarfólks og með hvaða hætti stuðningur er veittur (Guðrún V. Stefánsdóttir o.fl., 2014). Viðhorf viðmælenda virtust í flestum tilfellum byggja á einlægum áhuga og mikilli nánd í sambandi peirra við notendur. Svo virðist sem samband aðstoðarfólks við notendur hafi mikið um að segja hvernig pað mótar hlutverk sitt. Í hugmyndum um gagnkvæmni í aðstoð er lögð áhersla á mikilvægi pess að viðurkenna að sambandið byggi á gagnkvæmni og tilfinningalegum tengslum í báðar áttir frekar en að stilla sambandinu upp sem andstæðum (Walmsley, 1993; N. Watson o.fl., 2004). Petta var einmitt tilfellið hjá Snorra sem orðaði pað svo: „Mér finnst pað mjög greinilegt, sko, að mér pykir vænt um pau og peim pykir vænt um mig, eða pannig. Pú veist, pað er mjög greinilegt að okkur líður vel með hver öðrum, sko.“ Aðrir viðmælendur lýstu sambandinu eins og peir væru „góðir vinir“ eða lögðu áherslu á að notandi og aðstoðarfólk væru „í pessu saman“ pegar rætt var um námið.

Í nálguninni um pjónandi leiðsögn er lögð mikil áhersla á samband notanda og aðstoðarfólks og bent á nauðsyn pess að aðstoðarfólk líti svo á að pað sé skuldbundið notanda og hafi einlægan áhuga á samskiptum við hann (Gentle Teaching, e.d.; Van de Siepkamp o.fl., 2018). Erna lagði einmitt áherslu á mikilvægi pess að hafa einlægan áhuga á starfinu:

Рað er líka pessi áhugi. Af pví að pú gerir petta ekki bara af pví að petta er vinnan pín. Pú parft líka að hafa áhuga á pví sem pú ert að gera ... Pú parft að hafa áhuga á pví sem viðkomandi sem pú ert að aðstoða hefur áhuga á, pó pað fari eftir einstaklingum, pú veist ... Já, ég geri petta líka fyrir sjálfa mig.

Samband á milli aðstoðarfólks og notanda sem byggir á nánd og einlægum áhuga er einnig ein af grunnstoðum í virkum stuðningi par sem fjallað er um hið eflandi samband notanda og aðstoðarfólks sem forsendu fyrir góðum vinnubrögðum aðstoðarfólks (Mansell og Beadle-Brown, 2012). Berta lýsti mjög nánu sambandi við notanda og sýndi mikla næmni og mikinn skilning á pörfum notanda í ummælum sínum. Pað hafði áhrif á hvernig hún sá fyrir sér hlutverk sitt:

Hann talar ekki alltaf hátt og skýrt en getur pað alveg en gerir pað ekki alltaf. Og, pú veist, eftir öll pessi ár pá bara lærir maður náttúrlega inn á pað, og pá parf stundum bara að hjálpa við pví. En annars ekki, sko. Meira bara pegar hann er eitthvað lítill í sér eða er að sýna einhvers konar hegðun. Pá parf maður kannski bara að útskýra hvað pað er.

Sambandið á milli peirra gerði Bertu betur kleift að veita notanda öryggi pegar hann purfti á pví að halda. N. Watson o.fl. (2004), sem hafa fjallað um gagnkvæmni í aðstoð, benda einmitt á að gagnkvæm tengsl í sambandi aðstoðarfólks og notanda dragi athyglina að gagnkvæmum pörfum peirra. Í pjónandi leiðsögn er lögð áhersla á að náið samband aðstoðarfólks og notanda geti komið í veg fyrir erfiða hegðun notanda af pví að pað eykur öryggistilfinningu hans í erfiðum aðstæðum (McGee, 1992; Van de Siepkamp o.fl., 2018). Nánd í sambandinu við notanda stuðlar sem sagt að pví að aðstoðarfólk taki sér hlutverk stuðningsaðilans. Рað auðveldar aðstoðarfólki að sýna notanda 
skilning, einnig pó að erfið hegðun beinist að aðstoðarfólkinu sjálfu. Snorri lýsti pessu á eftirfarandi hátt:

Mér finnst skipta svo miklu máli að, pú veist, eins og Fríða, hún getur alveg verið, pú veist, agressíf og beitt mann ofbeldi en, pú veist, ég veit alveg að pað er ekki persónulegt gagnvart mér. Pað er bara, pú veist, hún er að sýna viðbrögð við einhverju í umhverfinu, hún er að sýna viðbrögð við einhverju áreiti eða eitthvað, sko. Og, hérna, og um leið og pað er búið, skilurðu, að pá er allt búið. Og mér finnst pað skipta svo miklu máli. Mér finnst pað skipta máli að ég geti líka litið á hana sem sömu manneskjunni og áður en hún, skilurðu, sló til mín eða hvað sem var, skilurðu.

Miklar kröfur eru gerðar til aðstoðarfólks að reyna að skilja pað sem liggur að baki erfiðri hegðun líkt og Snorri lýsir hér. Hugsanlega fer aðstoðarfólk í hlutverk hins hlutlausa fylgdarmanns ef pað upplifir ekki slíka nánd í sambandinu eða ef pað hefur ekki fengið nægilega góða pjálfun í að styðja notanda og veita honum öryggi.

Nokkrir viðmælendur nefndu dæmi pess að samstarfsfólk peirra væri „bara í vinnunni“ og reyndi að gera hlutina eins auðvelda og hægt væri fyrir sig. Berta sagði til dæmis: „En svo eru sumir, pú veist, maður er alveg, einhverjir starfsmenn sem bara: „Nei, ég nenni ekkert í göngu“ eða eitthvað, pú veist, pegar einstaklingurinn peirra biður um að fara út. Рað er svona, pað eru nokkrir pannig." Snorri útskýrði petta á eftirfarandi hátt:

Af pví að pað er svo auðvelt að fara að hugsa: „Petta er bara vinna.“ Og einhvern veginn, pú veist: „Рað er allt í lagi að vera í rútínu og fyrir mig að gera alltaf sömu hlutina, pað skiptir engu máli af pví að ég fæ borgað fyrir pað“ eða eitthvað.

Mansell og Beadle-Brown (2012), sem fjalla um virkan stuðning, halda pví fram að viðhorf aðstoðarfólks hafi afgerandi áhrif á hvernig pað vinnur. Ef viðhorfin eru ekki í lagi hefur innleiðing nýrra vinnubragða lítil áhrif. Viðmælendur lýstu mörgum dæmum par sem samstarfsfólk annaðhvort gleymdi eða nennti ekki að sinna peim verkefnum sem pví hafði verið falið í tengslum við nám notanda. Líney sagði um pátttöku aðstoðarfólks á ípróttanámskeiði með notanda: „En, já, ég veit að fólk er kannski mismikið að nenna að vera í boltaleikjum eða eitthvað svona en, pú veist, petta er bara partur af pví að vera með íbúunum." Erna sagði aðspurð um hvernig gengi að vinna verkefni heima sem kennari hafði sett fyrir: „Sumir gera pað og sumir bara gera pað aldrei, sumir gleyma pví bara. Peir hugsa: „Æ, kannski við förum bara á kaffihús eða eitthvað“. Ólík viðhorf aðstoðarfólks til starfsins geta pví haft mikil áhrif á hvernig aðstoðarfólk mótar hlutverk sitt og par með hvernig pað vinnur með notanda í náminu.

\section{Umræður og lokaorð}

Í pessari grein var lagt upp með pá spurningu hvernig aðstoðarfólk lítur á hlutverk sitt í námi fólks með proskahömlun sem parf mikinn stuðning. Niðurstöður rannsóknarinnar sýna að aðstoðarfólk í námi fólks með proskahömlun fékk hvorki skýrar leiðbeiningar frá yfirmönnum sínum né kennurum Fjölmenntar par sem notendur stunduðu nám. Skortur á leiðbeiningum og samtali um nám notenda varð til pess að aðstoðarfólkið deildi ekki sameiginlegri sýn á hlutverk sitt í náminu. Engu að síður mátti greina prjú mismunandi hlutverk í lýsingum viðmælenda sem skilgreind voru sem milliliður, stuðningsaðili og hlutlaus fylgdarmaður. Aðstoðarfólkið sem gekk inn í hlutverk milliliðs eða leit á sig sem stuðningsaðila hafði jákvæð áhrif á nám notenda. Раð auðveldaði samskipti milli notenda og kennara og veitti notendum nauðsynlegt öryggi til pess að taka pátt í náminu. Pegar aðstoðarfólk tók sér hlutverk hins hlutlausa fylgdarmanns var hins vegar hætta á að notandi missti af tækifæri til pátttöku í náminu par sem aðstoðarmanneskjan reyndi ekki að stuðla að pátttöku eða tjáningu.

Mikilvægt er að gera aðstoðarfólki kleift að taka sér hlutverk milliliðs og stuðningsaðila. Pað má meðal annars gera með pví að skilgreina hlutverkið betur og gefa aðstoðarfólki skýrari leiðbeiningar. 
Skortur á skilgreiningum og leiðsögn er í samræmi við fyrri rannsóknir á hlutverki aðstoðarfólks í skóla eða á heimili fatlaðs fólks sem parf mikinn stuðning (Chopra o.fl., 2004; Guðný Jónsdóttir og Snæfríður P. Egilson, 2013). Рað ber pó að hafa í huga að nám fullorðinna er ekki að öllu leyti sambærilegt námi barna í skólum en takmarkaðar rannsóknir á sviðinu og takmörkuð pátttaka fólks með proskahömlun sem parf mikinn stuðning í rannsóknum getur haft pau áhrif að óvissa ríki um hvernig styðja eigi við pað í námi. Prátt fyrir að aðstoðarfólkið starfi allt á heimili fólksins pá má færa rök fyrir pví að nám í símenntunarstöð sé frábrugðið daglegu lífi heima fyrir. Pað er lykilatriði að hlutverk aðstoðarfólks sé vel skilgreint, innan heimilisins og í námi notenda. Aðeins pannig er hægt að gera pví kleift að sinna starfi sínu samkvæmt peim markmiðum sem sett hafa verið með Samningi Sameinuðu pjóðanna um réttindi fatlaðs fólks (2007) og Lög um pjónustu við fatlað fólk með langvarandi stuðningsparfir (nr. 38/2018) um aðgengi að og stuðning í námi.

Pegar rýnt er í hlutverk aðstoðarfólks í námi fólks með proskahömlun er athyglisvert hvernig pað lítur á hlutverk kennarans en pað virðist hafa áhrif á hvaða hlutverk pað tekur sér í kennslustundum. Greint var frá prenns konar sýn á kennarann: Kennarinn sem jafningi, fyrirmynd og stjórnandi. Pegar aðstoðarfólk lítur á kennarann sem jafningja á pað mun auðveldara með að taka sér hlutverk milliliðsins og leiðbeina kennaranum eða taka viðábendingum frá honum. Ef litið er á kennarann sem fyrirmynd getur aðstoðarfólk lært nýjar leiðir til að eiga samskipti við notanda sem getur auðveldað pví að fara í hlutverk milliliðsins. Рað getur einnig lært ný vinnubrögð til að veita notanda öryggi sem auðveldar pví að fara í hlutverk stuðningsaðilans og grípa inn í fyrir hönd notanda ef pörf virðist á pví. Aðstoðarfólkið getur hins vegar einnig farið í hlutverk hins hlutlausa fylgdarmanns ef kennarinn er ekki meðvitaður um að hann geti verið fyrirmynd með viðbrögðum sínum. Ef aðstoðarfólk lítur á kennarann sem stjórnanda er svo að segja búið að rjúfa leiðirnar til pess að leiðbeina kennaranum, læra af honum eða grípa inn í fyrir hönd notanda, en pað leiðir auðveldlega til pess að aðstoðarfólk fari í hlutverk hins hlutlausa fylgdarmanns.

Mikilvægt er að kennarar í námi fólks með proskahömlun sem parf mikinn stuðning séu meðvitaðir um eigið hlutverk en svo virðist sem kennararnir sjálfir geti með framkomu sinni haft áhrif á sýn aðstoðarfólksins. Pess vegna er mikilvægt að kennarar leitist við að vinna sem jafningjar aðstoðarfólks frekar en stjórnendur og miðli pví jafnvel markvisst til aðstoðarfólks. Einnig er mikilvægt að kennarar geri sér grein fyrir að peir geti verið fyrirmynd aðstoðarfólks og að peir beiti sér markvisst í pví hlutverki par sem pað getur verið mikilvægur hluti af pví námi sem fer fram í kennslustundinni. Pað eru niðurstöður rannsóknarinnar og fyrri rannsókna að nám fólks með proskahömlun sem parf mikinn stuðning fer fram í nánu samspili við aðstoðarfólk pess (J. Watson, 2016).

Einnig kom fram að samband aðstoðarfólks við notendur getur skipt miklu máli. Aðstoðarfólk sem er í gagnkvæmu sambandi við notanda sem einkennist af einlægum áhuga og tilfinningalegum tengslum í báðar áttir virðist betur í stakk búið að taka sér hlutverk stuðningsaðilans pegar pörf krefur. Petta er í samræmi við nálgunina pjónandi leiðsögn, hugmyndir um gagnkvæmni í aðstoð og hugmyndir einstaklingsmiðaðs virks stuðnings um hið eflandi samband notanda og aðstoðarfólks (Gentle Teaching, e.d.; Mansell og Beadle-Brown, 2012; Thomas, 2007; Van de Siepkamp o.fl., 2018). Pess vegna er mikilvægt að huga vel að sambandi notanda og aðstoðarfólks, líkt og meðal annars hefur verið gert með innleiðingu bjónandi leiðsagnar í búsetupjónustu. Á hinn bóginn lýstu viðmælendurnir erfiðu vinnuumhverfi með mikilli starfsmannaveltu og manneklu sem virtist lita starfið og koma í veg fyrir markvisst samstarf og samtal um hlutverk aðstoðarfólks í námi notenda. Við slíkar aðstæður er erfitt fyrir stjórnendur að miðla peirri sameiginlegu sýn sem vinna á eftir og tryggja jákvæð viðhorf í garð starfsins og sambandsins við notendur.

Viðmælendur tóku mörg dæmi um samstarfsfólk sem annaðhvort gleymdi eða nennti ekki að sinna peim verkefnum sem pví hafði verið falið í tengslum við nám notanda. Рað sýnir að pörf sé á að bæta sérstaklega viðhorf aðstoðarfólks til náms notenda og færni til að aðstoða notendur við að nýta sér námið í daglegu lífi. Aðstoðarfólk sem sýnir námi notanda einlægan áhuga er mun líklegra til að taka sér hlutverk milliliðsins eða stuðningsaðilans eftir pví hver pörfin er hverju sinni til pess að auka pátttöku notanda í náminu. Fræðimenn hafa bent á að frammistaða aðstoðarfólks sé háð 
samanlögðum áhrifum af viðhorfum pess og færni (Mansell og Beadle-Brown, 2012). Pað er pví mikilvægt að vinna í báðum páttum og bæta bæði fræðslu og pjálfun fyrir aðstoðarfólk. Pað má gera með formlegri menntun par sem lögð er áhersla á pessa pætti en pað má einnig gera með reglulegri fræðslu og markvissum leiðbeiningum frá stjórnendum í búsetupjónustunni.

Reykjavíkurborg hefur undanfarið lagt áherslu á innleiðingu bjónandi leiðsagnar sem verkfæris til að framfylgja hugmyndafræðinni um sjálfstætt líf (Reykjavíkurborg, Velferðarsvið, 2018). Nálganir um pjónandi leiðsögn og virkan stuðning eiga margt sameiginlegt, meðal annars áhersluna á samband aðstoðarfólks og notanda og mikilvægi viðhorfa aðstoðarfólks. Niðurstöðurnar sem hér að framan hafa verið raktar benda til pess að með pví að innleiða virkan stuðning, einkum pær hugmyndir sem tengjast einstaklingsmiðuðum virkum stuðningi, sé hægt að bæta möguleika notenda töluvert til að taka pátt í námi. Áherslur einstaklingsmiðaðs virks stuðnings, varðandi að bæta bæði viðhorf og færni aðstoðarfólks og stuðla að hinu eflandi sambandi pess við notendur, falla vel að peim tillögum til úrbóta sem settar hafa verið fram hér að framan í ljósi niðurstaðna rannsóknarinnar. Рað sama á við um áherslu virks stuðnings á hvernig stuðningur aðstoðarfólks geti haft bein áhrif á hvort notandi verði virkur pátttakandi í daglegum verkefnum og ákvarðanatöku um eigið líf. Virkur stuðningur getur bætt pjónustuna, með pví meðal annars að styrkja aðstoðarfólk í að taka virkan pátt í námi notenda og stuðla pannig að pátttöku peirra í náminu, svo peir eigi raunverulega möguleika á að nýta sér nám til jafns við aðra.

\section{Intermediary, supporter or neutral escort. The role of assistants in lifelong learning of people with intellectual disabilities who require more intensive support.}

People with intellectual disabilities requiring more intensive support have had limited access to education and few opportunities to apply their learning in daily life. It is predicted that the percentage of those able to benefit from an assistant provided by their support service throughout lifelong learning will continue to grow, and it is thus necessary to better define the role of assistants in relation to the lifelong learning of disabled people. The purpose of this article is to present a research project with the goal of gaining insight into how assistants envision this role. The participants in this study were six assistants who had experience of attending courses at Fjölmennt, adult education centre with the people they assisted. The people who received assistance utilized augmentative methods of communication and needed intensive support from day to day. The interviews were carried out from March 2018 until January 2019. The findings suggest that the assistants mostly shape their roles themselves; that is, they receive limited instructions from their supervisor and the teacher at the adult education centre. The research revealed the ways in which the participants developed their positions, and three distinct types of assistantship roles were identified, referred to in this study as the intermediary, the supporter, and the neutral escorter. The role of the intermediary is based on the idea that the assistant knows the service user better than the teacher and can take on the role of an interpreter, which makes the lesson more successful. The intermediary also offers guidance to the teacher, based on the service users' life experiences relevant to their lessons. The role of the supporter is different and mostly focused on the service user. The supporter is present during lessons, mainly to provide the service user with a sense of security. This role demands a close relationship between the assistant and the service user and can have a positive influence on the service user's learning. The neutral escorter neither supports the service user nor the teacher during the lesson. His role is to transport the service user to the centre and assist with daily life activities. Sometimes the neutral escorter waits outside the classroom during the lesson. The neutral escorter will intervene if the service user's behaviour becomes challenging or threatening but neither takes part in preventing this from occurring nor analysing what the service user is trying to communicate with his behaviour. Thus the service user might lose a chance to take 
part in a lesson if the assistant takes on the role of the neutral escorter. What influenced which roles the personal assistants adopted was based on factors such as how they viewed the role of the teacher and their own ideas about being assistants and about the importance of lifelong learning for the people they assisted. If they viewed the teacher as an equal, the personal assistants took on the role of the intermediary and there was much focus on cooperation and a mutual flow of information. Those who viewed the teacher as a role model were eager to learn and tried to adopt to the practices in the classroom but which role the assistant took on depended on whether the teacher was aware of his own function as a role model. Those who viewed the teacher as the leader, or the boss of the lesson took on the role of neutral escorters or were at least less eager to speak up for the service user as intermediaries or supporters. Therefore, the teacher's attitude and approach to the service user and their assistants can influence how the assistants carry out their support during the lessons. The findings also suggest that since the assistants shape their role mostly themselves; their own ideas about being assistants will influence their support. The findings particularly suggest that a close relationship between the assistant and the service user will influence the support in a positive way. From these results it may be concluded that guidelines on the assistants' role need improvement and clarification along with teachers' awareness of their own role in their cooperation with the assistants. Improvements need to be made in emphasizing the importance of lifelong learning and of the transfer of learning for people with intellectual disabilities requiring more intensive support. The results of this study suggest that the introduction of an active support approach in residential services could facilitate the role of assistants who support disabled people in their lifelong learning. This would have a positive effect on the opportunities of people with intellectual disabilities requiring more intensive support towards receiving an education equal to that of others.

Key words: Assistants, people with intellectual disabilities who require more intensive support, lifelong learning, active support

\section{Um höfunda}

Helle Kristensen (helle@fjolmennt.is) er kennari og verkefnastjóri hjá Fjölmennt, símenntunar- og pekkingarmiðstöð oghefur kennt parfráárinu 2007. Hún lauk B.Ed.-námiígrunnskólakennarafræðum frá Kennaraháskóla Îslands árið 2006 og M.Ed.-prófi í sérkennslufræði og skóla margbreytileikans frá Háskóla Íslands 2019. Helle hefur fjölbreytta reynslu af starfi með fötluðu fólki, meðal annars sem aðstoðarmaður í lýðháskóla og á heimili og einnig sem stuðningsforeldri. Starf hennar hjá Fjölmennt hefur sérstaklega beinst að innleiðingu snjalltækja í kennslu og daglegu lífi sem og samstarfi við starfsfólk pátttakenda í búsetupjónustu.

Kristín Björnsdóttir (kbjorns@hi.is) er prófessor í fötlunarfræði og sérkennslu við Menntavísindasvið Háskóla Î́slands. Hún lauk BM-prófi í músíkperapíu frá East Carolina University í Bandaríkjunum 1997, fékk kennsluréttindi í grunn- og framhaldsskóla 1999, lauk meistaraprófi í uppeldis- og menntunarfræðum frá Háskóla Íslands 2002 og doktorsprófi í fötlunarfræðum frá Háskóla Íslands 2009. Auk pess stundaði hún nám í fötlunarfræði við University of Sheffield í Bretlandi. Kristín starfaði um árabil með fötluðum börnum og ungmennum í skólakerfi og tómstundum. Rannsóknir hennar hafa einkum beinst að skólagöngu og samfélagspátttöku fólks með proskahömlun og samspili menningar, kyngervis og fötlunar. Kristín var umsjónarmaður starfstengds diplómunáms fyrir fólk með proskahömlun og námsleiðar í sérkennslufræðum við Menntavísindasvið Háskóla Íslands.

\section{About the authors}

Helle Kristensen (helle@fjolmennt.is) is a teacher and project manager at Fjölmennt - Adult Education Center and has worked there since 2007. She completed a B.Ed. degree in Teacher 
Education at Iceland University of Education in 2006 and received an M.Ed. degree in Inclusive Special Education from the University of Iceland in 2019. Helle has varied experience of working with disabled people, for example as an assistant in a folk high school and in a person's home as well as being a parental support. Her job at Fjölmennt has mainly been concerned with implementing smart devices in teaching and in daily life and cooperation with students' staff in residential services.

Kristín Björnsdóttir (kbjorns@hi.is) is Professor of Disability Studies in Education at the School of Education, University of Iceland. She completed a BM degree in Music Therapy from East Carolina University in 1998, earned her certificate as a compulsory school and upper secondary school teacher in 1999, and received an MA degree in Education from the University of Iceland in 2002 and a $\mathrm{PhD}$ in Disability Studies from the same university in 2009. She also studied Disability Studies at the University of Sheffield. Kristín's teaching experience spans all levels from pre-primary school to higher education. Her research interests are mainly in the fields of inclusive education, disability and gender. Kristín has served as programme coordinator for the Vocational Diploma programme for students with intellectual disabilities and the Special Education programme at the School of Education, University of Iceland.

\section{Heimildaskrá}

Ástríður Stefánsdóttir. (2013). Eigindlegar rannsóknir og siðferðileg álitamál. Sérrit Netlu 2013 - Rannsóknir og skólastarf. Sótt af http://netla.hi.is/serrit/2013/rannsoknir_og_skolastarf/002.pdf

Beadle-Brown, J., Mansell, J., Ashman, B., Ockenden, J., Iles, R. og Whelton, B. (2014). Practice leadership and active support in residential services for people with intellectual disabilities: An exploratory study. Journal of Intellectual Disability Research, 58(9), 838-850. doi:10.1111/jir.12099

Braun, V. og Clarke, V. (2013). Successful qualitative research: A practical guide for beginners. London: SAGE.

Chopra, R. V., Sandoval-Lucero, E., Aragon, L., Bernal, C., Balderas, H. B. D. og Carroll, D. (2004). The paraprofessional role of connector. Remedial and Special Education, 25(4), 219-231. doi:10.1177/074193 25040250040501

Dalton, C. og Sweeney, J. (2011). Communication supports in residential services for people with an intellectual disability. British Journal of Learning Disabilities, 41(1), 22-30. doi:10.1111/j.1468-3156.2011.00717.x

Fjölmennt. (e.d.). Um Fjölmennt. Sótt af http://www.fjolmennt.is/is/um-fjolmennt

Flick, U. (2006). An introduction to qualitative research. London: SAGE.

Gentle Teaching. (e.d.). An overview on gentle teaching. Sótt af https://www.gentleteaching.nl/gentle/en/watis-en/overview

Giangreco, M. F., og Doyle, M. B. (2007). Teacher assistants in inclusive schools. Í L. Florian (ritstjóri.), The SAGE handbook of special education (bls. 429-439). London: Sage. doi:10.4135/9781848607989.n33

Gretar L. Marinósson (ritstjóri). (2007). Tálmar og tekifari. Menntun nemenda með proskahömlun á Íslandi. Reykjavík: Háskólaútgáfan.

Guðný Jónsdóttir og Snæfríður P. Egilson. (2013). „Við gerum bara eins og við getum“ - Pjónusta við fólk með fjölpættar skerðingar. Stjórnmál og stjórnsýsla, 9(1), 171-190. doi:10.13177/irpa.a.2013.9.1.9

Guðrún V. Stefánsdóttir, Kristín Björnsdóttir og Ástríður Stefánsdóttir. (2014). „Má ég fá að ráða mínu eigin lífi?“ Sjálfræði og fólk með proskahömlun. Uppeldi og menntun, 23(2), 21-41.

Guðrún V. Stefánsdóttir. (2015). Sjálfræði og fólk sem parf mikinn stuðning í daglegu lífi: „Við höfum alltaf gert petta svona, pað er peim fyrir bestu“. Sérrit Netlu 2015 - Hlutverk og menntun proskapjálfa. Sótt af http://netla.hi.is/serrit/2015/hlutverk_og_menntun_throskathjalfa/002.pdf

Guðrún V. Stefánsdóttir og Kristín Björnsdóttir. (2018). Meaningful participation and shared ownership in an inclusive university program in Iceland. Í P. O’Brien, M.L. Bonati, F. Gadow og R. Slee (ritstjórar), People with intellectual disability experiencing university life: Theoretical underpinnings, evidence and lived experience (115-128). Leiden: Koninklijke Brill NV, Leiden 
Lichtman, M. (2013). Qualitative research in education: A user's guide (3. útgáfa). London: SAGE.

Lög um pjónustu við fatlað fólk með langvarandi stuðningsparfir nr. 38/2018.

Mansell, J. og Beadle-Brown, J. (2012). Active support: Enabling and empowering people with intellectual disabilities. London: Jessica Kingsley.

Mansell, J., Beadle-Brown, J., Ashman, B. og Ockendon, J. (2005). Person-centered active support: A multimedia training resource for staff to enable participation, inclusion and choice for people with learning disabilities. Brighton: Pavillion.

Mansell, J., Elliott, T., Beadle-Brown, J., Ashman, B. og Macdonald, S. (2002). Engagement in meaningful activity and "active support" of people with intellectual disabilities in residential care. Research in Developmental Disabilities, 23(5), 342-352. doi:10.1016/S0891-4222(02)00135-X

María Hildipórsdóttir. (2006). Möguleikar fatlaðs fólks til náms að loknum framhaldsskóla (óútgefin meistararitgerð). Sótt af http://www.fjolmennt.is/static/files/rannsoknir/moguleikar-fatlads-folks-til-nams.pdf

McGee, J. J. (1992). Gentle teaching's assumptions and paradigm. Journal of Applied Behavior Analysis, 25(4), 869-872. Sótt af https://www.ncbi.nlm.nih.gov/pmc/articles/PMC1279770/

Morris, J. (1997). Care or empowerment? A disability rights perspective. Social Policy \& Administration, 31(1), 54-60. doi:10.1111/1467-9515.00037

O’Brien, P., Bonati, M.L., Gadow, F. og Slee, R. (ritstjórar) (2019). People with intellectual disability experiencing university life: Theoretical underpinnings, evidence and lived experience. Leiden: Koninklijke Brill NV, Leiden

Pockney, R. (2006). Friendship or facilitation: People with learning disabilities and their paid carers. Sociological Research Online, 11(3), 89-97. Sótt af http://www.socresonline.org.uk/11/3/pockney.html

Reykjavíkurborg, Velferðarsvið. (2018). Sjálfstett lif. Valdeflandi stuðningur og aðstoð. Sótt af https://reykjavik.is/ sites/default/files/ymis_skjol/skjol_utgefid_efni/velferdarsvid_210x210_hugmyndafraedi_sjalfstaett_lif_20._ april_2018.pdf

Samningur Sameinuðu pjóðanna um réttindi fatlaðs fólks /2007.

Sigurbjörg J. Helgadóttir og Hildur Björk Svavarsdóttir. (2006). Greining á starf: Stuðningsfulltrúar ígrunnskólum Reykjavíkur. Sótt af https://reykjavik.is/sites/default/files/ymis_skjol/skjol_utgefid_efni/studningsfulltr_ar-lokaskyrsla.pdf

Snæfríður Póra Egilson og Rannveig Traustadóttir. (2009). Assistance to pupils with physical disabilities in regular schools: Promoting inclusion or creating dependency? European Journal of Special Needs Education, 24(1), 21-36. doi:10.1080/08856250802596766

Thomas, C. (2007). Sociologies of disability and illness. Contested ideas in disability studies and medical sociology. New York: Palgrave Macmillan.

Toogood, S., Totsika, V., Jones, E. og Lowe, K. (2016). Active support. Í N. N. Singh (ritstjóri), Handbook of evidence-based practices in intellectual and developmental disabilities (bls. 537-560). doi:10.1007/978-3319-26583-4_20

Totsika, V., Toogood, S. og Hastings, R. P. (2008). Active support: Development, evidence base, and future directions. International Review of Research in Mental Retardation, 35, 205-249. doi:10.1016/s00747750(07)35006-4

Van de Siepkamp, P., McCrovitz, A. M. og Vincent, M. (2018). Defining gentle teaching. Based on the life work of dr. John McGee. Sótt af https://strategydev20.com/gti/wp-content/uploads/2019/12/181002-De\%EF\% AC\%81ning-Gentle-Teaching.pdf

Walmsley, J. (1993). Contradictions in caring: Reciprocity and interdependence. Disability, Handicap \& Society, 8(2), 129-141. doi:10.1080/02674649366780111

Watson, J. (2016). Assumptions of decision-making capacity: The role supporter attitudes play in the realisation of article 12 for people with severe or profound intellectual disability. Laws, 5(1), 6. doi:10.3390/laws5010006

Watson, N., McKie, L., Hughes, B., Hopkins, D. og Gregory, S. (2004). (Inter)Dependence, needs and care. The potential for disability and feminist theorists to develop an emancipatory model. Sociology, 38(2), 331-350. doi:10.1177/0038038504040867 
Windley, D. og Chapman, M. (2010). Support workers within learning/intellectual disability services perception of their role, training and support needs. British Journal of Learning Disabilities, 38(4), 310-318. doi:10.1111/j.1468-3156.2010.00610.x

Pórunn Kjartansdóttir. (2016). „Ég myndi ekki vilja vera án gódra stuðningsfulltrúa, pað er alveg á hreinu“: Páttur stuðningsfulltrúa i menntastefnunni skóli án aðgreiningar (óútgefin meistararitgerð). Sótt af http://hdl.handle. net/1946/26252

Helle Kristensen og Kristín Björnsdóttir.. (2020).

Milliliður, stuðningsaðili eða hlutlaus fylgdarmaður. Hlutverk aðstoðarfólks í námi fólks með proskahömlun sem parf mikinn stuðning. Netla - Veftímarit um uppeldi og menntun: Sérrit 2020 - Menntavika 2020.

Sótt af http://netla.hi.is/serrit/2020/menntavika_2020/02.pdf

DOI: https://doi.org/10.24270/serritnetla.2020.8 